\title{
Linguistic disciplines as a factor of the general cultural competence formation of the future specialists
}

\author{
Elena Bukhvalova ${ }^{1, *}$ \\ ${ }^{1}$ Samara State Agrarian University, Kinel, 446442, Russia
}

\begin{abstract}
The article deals with the problem of the general cultural competence formation in the process of learning English by students in the framework of the introduction of new educational standards in higher education. The author examines the process of the general cultural competence formation that focuses a future specialist's attention on universal values in the modern society, allows one to understand a situation and to solve problems in various fields of activity, to develop personally and professionally. Particular attention is paid to the general cultural competence formation based on the cycle of linguistic disciplines which is an essential component in the training competitive specialists who are able to adapt easily to smart and digital technologies and innovations. The technological approach promoting general cultural competences formation based on the cycle of linguistic disciplines is given.
\end{abstract}

\section{Introduction}

Modern society requires the education system to train erudite, highly cultured specialists who are able to adapt easily to the changing conditions of the society. The goal of education is a person with a certain set of knowledge, skills, professional, moral and ethical qualities. The minimum list of such requirements for a graduate of an educational institution is formulated in state educational standards. It is stated that an educated person is able to socialize effectively and acts as a bearer of the culture of his community.

The project "Strategy for the education development in the Russian Federation until 2025" is aimed at the effective development of such qualitative characteristics of students as spiritual and moral valuable orientations; motivation for continuous personal development; communicative and socially significant skills and experience that contribute to the social and civil development of the personality, successful self-realization in life, society and profession. Taking this fact into consideration, the priority task for a higher educational institution is the organization of the educational process, which ensures the conditions for the students to develop skills for independent solving problems based on their own knowledge. For this reason, the content of the training program is becoming a means of developing personal components of general cultural competence.

Some authors define and interpret the term "competence" as "the ability to respond to the demands or carry out tasks successfully". This concept refers to attitudes, abilities skills and performance abilities. As can be seen, the concept of competence includes knowledge, know-how and knowledge to be, so people acquire and develop skills to foster their development as individuals and as professionals [1].

The signed Bologna Convention that unites universities in the Common European system of higher education takes aim at more active use of a foreign language as a means of communication. Each graduate has to master a wide range of competencies, knowledge and skills. According to this, the higher education system focuses on the formation of a multicultural personality of a competitive specialist with sociocultural knowledge and scientific outlook. Nowadays there is a change of priorities, it is becoming possible to strengthen the cultural-forming role of education, a new student's ideal appears - "a person of culture" with general cultural competence.

The role of the humanitarian disciplines in the general cultural competencies formation has been actualized recently. The subjects of the humanitarian block are of great importance for the development of the student's personality $[2,3]$. Therefore, they contribute to:

the development of creative activity;

the formation of personal readiness to apply professional knowledge and skills;

the development of communication and organizational skills;

the human (humanistic) values formation;

mastering knowledge of work psychology and culture; the development of the ability to continuous education during life.

The human potential greatly depend on the humanitarian paradigm of education because it is based on the creative skills development and the formation of moral ideas [4]. The humanitarian component as a factor in raising the cultural level of students implies a purposeful activity of the subject of pedagogical practice

\footnotetext{
*Corresponding author: bukhvlena@mail.ru
} 
in creating an educational process project that involves the gradual alignment of the process of student humanitarian training, describes its structure, links, methodological grounds and component composition, justifies the goals, tasks, forms of pedagogical interactions [5].

General cultural competence includes the following:

- knowledge of world culture;

- knowledge and understanding the laws of nature and society and the ability to operate with this knowledge;

- the ability to analyze and evaluate historical processes and events;

- the ability to take an active civil position.

It should be mentioned that the general cultural competencies formation is possible if the process of study is organized in accordance with the principles of teaching, including general pedagogical ones such as:

the principle of continuity of education - the formation of a specialist of different skill levels achieved after mastering appropriate training programs;

the principle of consistency - links between the goal, content, process and studying outcomes ensuring knowledge integrity;

the principle of a humanistic approach to education an orientation towards respecting the human dignity of the student creating the necessary conditions for his development;

the principle of personal and creative development the development of the abilities and qualities of the person and individuality: knowledge of the career mechanisms and creative growth in the team; the ability to realize communicative and leading qualities, business skills in various activities in co-management, as well as in the career promotion and creative growth; development of valuable principles; communication skills with colleagues, administration, etc.

It is the general cultural competence that determines the active life of a person, his ability to understand different fields of social and professional life. Knowledge of linguistic disciplines is an essential component of the general culture of a specialist in the modern world. In particular, it becomes urgent to form the content of education and implement it in training based on the cycle of linguistic disciplines (a mother tongue, a language of international communication and a foreign language. Basis on a module of linguistic disciplines in relations with the content of general and professional education contributes to the mutual enrichment of Russian and foreign languages, filling both of them with socio-cultural and historical-cultural knowledge, the fundamentalization of general cultural knowledge.

The study of the history of culture shows that attitude toward the language, native and foreign, is always an indicator of social and socio-psychological processes in society, only fair language policy of a democratic state can ensure equality in the language competence of citizens. Linguistic disciplines are unique for the spiritual and moral development and the formation of the general culture of a specialist. The pedagogical potential of a foreign language includes a system of educationally significant components: content (knowledge of the national and cultural peculiarities of the realities of the country which language is studied);

activity (level of practical knowledge of the language); communicative (ways to interact with people around you);

intercultural (awareness of human values in the intercultural communication);

emotional (positive attitude to the phenomena from the point of socially and personally significant values, empathy).

\section{Materials and Methods}

A range of complementary methods is used in this research including:

theoretical methods: analysis of philosophical, psychological and pedagogical literature on the problem of study, theoretical analysis;

empirical methods: pedagogical observation, questioning, testing, analysis and generalization of pedagogical experience, processing of research results.

A foreign language as a discipline covers all aspects of people's lives, a lot of different things are to be studied. Students develop general cultural competence participating in discussions, choosing situations, analyzing texts, studying the peculiarities of national culture, cultural background of social traditions and phenomena. It should be noted that the forms and types of classes are also important: project activities, presentations, quizzes that develop cognitive, analytical and search activity, thinking variability, the ability to cooperate, convince, show erudition. Linguistic disciplines also contribute to the formation of personal qualities, tolerance to cultural diversity and understanding of social values. An important final stage of any class is the analysis of the work done (reflection). Students analyze their own and classroom activities choosing the beginning of the phrase, for example, "today I learned ..., it was interesting ..., I can ..., it was difficult ..., I could ....".

Teachers of a foreign language should also take into account general methodological principles, the main ones are:

the principle of communication. Studied language is used for general purposes and functions for communication or in situations imitating them. Thus, in the process of studying a foreign language future professional activities should be imitated as much as possible;

the principle of interconnected teaching the types of speech activity;

the principle of authenticity;

principle of intensification of the educational process; the principle of studying both language and culture;

the principle of professional-oriented training.

Studying foreign and Russian languages, it is necessary to ensure the general cultural competences formation with social, labor and professional orientation to develop skills in various social roles in the sphere of civil, social and future professional activities. To 
accomplish this task it is advisable to use active and interactive teaching methods including in the content of teaching the following:

the spheres of communication activities, themes and situations, speech actions and material taking into account the professional orientation of students;

the language material (phonetic, lexical, grammatical, spelling), the rules of using it;

a set of special (speech) skills that characterize the level of practical knowledge of a foreign language as a means of communication;

knowledge system of national-cultural features and realities of the language studied.

\section{Results}

Thus, in the process of teaching a foreign language students develop skills which are an integral part of general cultural competencies such as the ability to learn, to explain the phenomena of reality; the ability to solve the key problems of the modern life - ecological, political, intercultural interaction and others. This also includes the ability to understand inner world values reflecting different cultures and outlook; the ability to solve the problems connected with the implementation of certain social roles; and the ability to solve problems common to various types of professional and other activities (communication, search and analysis of information, decision-making, organization of joint activities) and many others.

The competencies formation is implemented through various educational technologies [6]. The most popular technologies are personality-oriented: learning in collaboration, project method, multilevel learning, individual and differentiated approach. These technologies create the necessary conditions for a student to develop certain personal qualities. The use of such teaching forms makes the student to play the main role in the mastering knowledge where the teacher creates conditions for independent creative search, prompting for research activities.

Our research was carried out on the basis of didactic support of humanitarian content of the linguistic disciplines as a part of scientific standards - principles, sources, criteria for the formation of humanitarian education content and specific principles for selecting the content of linguistic disciplines.

The construction of educational material based on the cycle of linguistic disciplines involves the integration between languages and other subjects. The following actions are proposed for the technological construction of educational material:

1) analysis of the program (course) of the studied linguistic discipline and the theme formulation;

2) selection of the content of educational material of interdisciplinary type;

3) identification of the theme's links with the content of the subject studied (intra-subject relations);

4) selection of interdisciplinary content in related and other general and professional disciplines;
5) definition of methods, techniques and forms of presentation of educational material of interdisciplinary type;

6) types definition of interdisciplinary connections.

Teaching languages on an intercultural basis (interdisciplinary connections with the Russian native language, Russian literature, history, etc.) contributes to the formation of an emotional-valuable attitude to linguistic subjects. The technological approach to the content construction contributes to raising the effectiveness of training obtaining general cultural knowledge, stimulates an integrated method to the study of languages, making teachers to conduct a comparative analysis of the phenomena of foreign and Russian culture, the formation of a valuable attitude to the language, the specification of objectives and criteria for their achievement. So, the technological approach in studying grammar based on the cycle of linguistic disciplines and comparing them allows one to satisfy the cognitive interests of students and increase their motivation to a greater extent. The analysis of the role of grammar in the formation of personality and national character shows that even with an insignificant example of the use of an exclamation mark in English and Russian, a tendency towards increased emotionality among native speakers of the Russian language is revealed in contrast to the English understatement. Unlike English, in the Russian language there is a more frequent use of an exclamation mark which indicates greater emotionality and open emotions. The grammatical system reflects the sociocultural norms accepted in the society, the mentality of the people. It is known that openness, emotionality, sentimentality are characteristic features of the Russian mentality, while understatement, flatness are for the British one. Thus, technologies based on the Russian language in achieving high results in teaching English are applicable to work on both linguistic and regional studies, as well as lexicogrammatical and speech material.

The construction of curriculum and educational material by means of technological approach contributes to communicative studying that is essential in the modern society. Not only the language but also the behavior of the speaker in terms of verbal communication is also important.

The experimental work was carried out in the following directions:

1) teachers' self-training to develop and apply technologies of the construction of educational material based on the cycle of linguistic disciplines;

2) students' progress to achieve the general cultural competence by means of technological approach to the construction and implementation of the content of linguistic disciplines supplemented by specific principles for linguistic disciplines.

In the course of the experimental work, the possibilities of improving the content of the education of foreign languages and the Russian language as humanitarian subjects in the system of forming the content of general education were identified. Taking into account the particularity of disciplines of the linguistic 
cycle we supplemented the content of education with the following principles:

- reflection of the historical relationship of communication acts among themselves;

- expression of public consciousness in the language;

- formation, adoption and preservation of culture.

The concept of general culture in this research is considered as kinds of the content of general education knowledge about the world, experience in implementing methods of activity, experience in creative activities, experience in emotional-valuable relationships to reality. Accordingly, the concept of general culture is considered as the possession of this system of educational content. As a result of the experimental work positive changes in students' attitude towards foreign and Russian languages were revealed. Students showed more interest to the cultural component in the content of linguistic disciplines and linguistic material on the whole. Before the experiment students studied a language as a means of selfrealization in the society and as an additional means of communication. This can be explained by the fact that nowadays specialists with good knowledge of a foreign languages are in demand. Moreover, practical skills had been the main goal of studying languages for many years, with few hours of studying a week.

We also observed a change in students' interest in the study of linguistic disciplines. The main motives for learning a foreign language were "every educated person must know at least one foreign language", "a foreign language is necessary for my further promotion in the chosen profession", "I study because it is obligatory". After the experimental work the students found language learning informative and useful, most students (78\%) believed that classes of a foreign language introduce new information about the country of the language being studied, about various aspects of life, allowing one to discuss and analyze environmental problems, law, ethics, and art. Students became interested in the etymology of words in both Russian and English. Furthermore, students tend to the following opinion: a foreign language promotes cultural introduction and broadens horizon; it helps to understand better the native language and in this way there is a wish to know more about Russia and culture. Thus, it was important to reveal changes in valuable features of general culture. Nevertheless, increasing the hours of language studying remains the main problem. Mastering the technologies of curriculum and educational material construction is necessary to achieve the above results in teaching linguistic disciplines.

\section{Discussion}

The experimental work shows that teaching linguistic disciplines based on a cycle of linguistic disciplines and technological construction of educational material contributes to the greater development of general cultural knowledge, foreign language, historical, cultural and socio-cultural competence, solving the problems of mastering professional educational programs by students, understanding the role of growing technical and technological projects regarding human activity and the fundamental nature of the general education of a person.

The general cultural competence formation merges with the formation of communication skills in foreign language studying and generally implements the same educational, practical and developmental goals, the achievement of which is aimed at teaching a foreign language to a particular contingent of students. A future specialist should be ready for continuous education during the life, to analyze any information quickly, take decisions and communicate effectively. The general cultural competence formation in the process of language learning provides better adaptation for future specialists and successful socialization in the changing world. It is justified that in modern conditions of the educational process it becomes necessary to develop the valuable attitude to language studying as it provides personal and professional development.

\section{References}

1. N.F. Plotnikova, E.N. Strukov, Cypriot Journal of Educational Sciences 14, 1-10 (2019)

2. G.B.Andreeva, Problems of modern science and education 6 (2015)

3. O.V. Stukalova, V.V. Kudryavtseva, E.A. Ganaeva, M.Y. Fadeyeva, O.M. Osiyanova, V.V. Natochy, Espacios 39 (2018)

4. E.M. Dorozhkin, A.M. Kalimullin, G.N. Migacheva, , T.B. Sokolova, EURASIA Journal of Mathematics, Science and Technology Education 14, 859-876 (2018)

5. L.V. Kochneva, T.E. Zulfugarzade, N.S. Aleksandrova, T.I. Shulga, L.Y. Grudtsina, Y.V. Nikolaeva, Espacios 39, 23 (2018)

6. O.G. Byrdina, S.G. Dolzhenko, E.A. Yurinova, Novosibirsk State Pedagogical University Bulletin 8, 7-25 (2018)

7. G.Z. Fahrutdinova, K.N. Bulatbayeva, O.I. Kondratova, S.N. Fedorova, O.A. Petukhova, XLinguae 11, 239-255 (2018)

8. L.V. Kochneva, T.E. Zulfugarzade, N.S. Aleksandrova, T.I. Shulga, L.Y. Grudtsina, Y.V. Nikolaeva, Espacios 39, 23 (2018)

9. I.I. Golovanova, N.V.Telegina, N.V., O.I. Donetskaya, Education and Self-development 14, 5767 (2019)

10. L.V. Orinina, I.V. Kashuba, I.V. Samarokova, Perspectivy Nauki i Obrazovania 37, 316-326 (2019)

11. M.R. Menke, K. Paesani, Language, Culture and Curriculum 32, 34-39 (2018)

12. T.Y. Yurevna, Perspectivy Nauki i Obrazovania 33, 317-321 (2018) 